\title{
Correction
}

\section{Correction to: Stress Inversion of Regional Seismicity in the Sea of Marmara Region, Turkey}

The article "Stress Inversion of Regional Seismicity in the Sea of Marmara Region, Turkey", written by Wollin et al., was originally published electronically on the publisher's internet portal (currently SpringerLink) on 03 September 2018 without open access.

With the author(s)' decision to opt for Open Choice the copyright of the article changed on November 2018 to (C) The Author(s) 2018 and the article is forthwith distributed under the terms of the Creative Commons Attribution 4.0 International License (http:// creativecommons.org/licenses/by/4.0/), which permits use, duplication, adaptation, distribution and reproduction in any medium or format, as long as you give appropriate credit to the original author(s) and the source, provide a link to the Creative Commons license and indicate if changes were made.

Open Access This article is distributed under the terms of the Creative Commons Attribution 4.0 International License (http://creativecommons.org/licenses/by/4.0/), which permits unrestricted use, distribution, and reproduction in any medium, provided you give appropriate credit to the original author(s) and the source, provide a link to the Creative Commons license, and indicate if changes were made.

The original article can be found online at https://doi.org/10.1007/ s00024-018-1971-1.

1 German Research Center for Geosciences, Section 4.2: "Geomechanics and Rheology", Telegrafenberg, 14473 Potsdam, Germany. E-mail: wollin@gfz-potsdam.de

2 Institute of Geophysics of the Czech Academy of Science, Bocni II/1401, 14100 Praha 4, Czech Republic. 